\title{
Two new sesquiterpenes from the stems of Miliusa velutina
}

Van Nguyen Thien, Truong; Vo, Thi Kieu Loan ; Dang, Phu Hoang ; Ngoc, Vinh Huynh ; Ngo, Thi Thuy Duong ; Nguyen, Thi My-Nuong ; Hansen, Poul Erik; That, Quang Ton

Published in:

Natural Product Research

DOI:

10.1080/14786419.2020.1789984

Publication date:

2022

Document Version

Peer reviewed version

Citation for published version (APA):

Van Nguyen Thien, T., Vo, T. K. L., Dang, P. H., Ngoc, V. H., Ngo, T. T. D., Nguyen, T. M-N., Hansen, P. E., \& That, Q. T. (2022). Two new sesquiterpenes from the stems of Miliusa velutina. Natural Product Research, 36, 553-559. https://doi.org/10.1080/14786419.2020.1789984

\section{General rights}

Copyright and moral rights for the publications made accessible in the public portal are retained by the authors and/or other copyright owners and it is a condition of accessing publications that users recognise and abide by the legal requirements associated with these rights.

- Users may download and print one copy of any publication from the public portal for the purpose of private study or research.

- You may not further distribute the material or use it for any profit-making activity or commercial gain.

- You may freely distribute the URL identifying the publication in the public portal.

Take down policy

If you believe that this document breaches copyright please contact rucforsk@kb.dk providing details, and we will remove access to the work immediately and investigate your claim. 


\title{
Two new sesquiterpenes from the stems of Miliusa velutina.
}

Truong Van Nguyen Thien ${ }^{\mathrm{a}, \mathrm{c}}$, Thi Kieu Loan $\mathrm{Vo}^{\mathrm{a}, \mathrm{c}}$, Phu Hoang Dang ${ }^{\mathrm{a}, \mathrm{c}}$, Vinh Huynh Ngoc ${ }^{\mathrm{a}, \mathrm{c}}$, Thi Thuy Duong Ngo ${ }^{\mathrm{a}, \mathrm{c}}$, Thi My Nuong Nguyen ${ }^{\mathrm{b}, \mathrm{c}}$, Poul Erik Hansen ${ }^{\mathrm{d},{ }^{*}}$ and Quang Ton That ${ }^{\mathrm{a}, \mathrm{c},{ }^{*}}$

${ }^{a}$ Faculty of Chemistry, University of Science, Ho Chi Minh City, Vietnam.

${ }^{b}$ Faculty of Biology and Biotechnology, University of Science, Ho Chi Minh City, Vietnam.

${ }^{c}$ Vietnam National University, Ho Chi Minh City, Vietnam.

${ }^{\mathrm{d}}$ Department of Science and Environment, Roskilde University, Roskilde, Denmark.

Corresponding Author Email: ttquang@hcmus.edu.vn

\begin{abstract}
From the ethyl acetate extract of the stems of Miliusa velutina, seven compounds (1-7) were isolated, including two new compounds such as mivelutina A acid (1), mivelutina B acid (2) and one known compound mivelutina B methyl ester (3). For this NMR data were not known previously. Their relative structures were elucidated based on NMR spectroscopic analysis. The absolute configuartions were determined based on DFT calculations of ${ }^{13} \mathrm{C}$ chemical shifts. All of the seven compounds were screened for their in vitro cytotoxic activities against HepG2 cell line using the SRB assay. Epoxyconiferyl alcohol (7) showed the highest potential for the cytotoxicity of cancer cell lines HepG2 with the $\mathrm{IC}_{50}$ values of $95.94 \mu \mathrm{g} / \mathrm{mL}(527 \mu \mathrm{M})$.
\end{abstract}

Keywords: Miliusa velutina, sesquiterpene, epoxyconiferyl alcohol, HepG2, mivelutina.

\section{Introduction}

Miliusa velutina is widely distributed in the Asian countries India, Laos, Myanmar, 
Cambodia, Thailand and Vietnam. Recent studies revealed that the chemical constituents of Miliusa velutina showed the presence of acetogenins (Jumana et al. 2000; Wongsa et al. 2011), alkaloids (Hasan et al. 2000; Jumana et al. 2000; Nguyen et al. 2017), flavonoids (Wongsa et al. 2017), phenylpropanoids (Jumana et al. 2000), steroids and terpenoids (Hasan et al. 2000). Bioactivities of these types of compounds were also studied in case of anti Plasmodium falciparum, antifungal, anti-cancer effects and two compounds, acetogenins A, B showed antibacterial activity by the disk diffusion assay and cytotoxicity by the brine shrimp lethality bioassay (Jumana et al. 2000).

In Vietnam, Miliusa velutina is the traditional medicinal plant, which was used to cure cancer, parasitic disease, and used as a natural pesticide (Vo Van Chi. 1991). Not many results are available so research on Miliusa velutina seems very timely. Our research showed that sesquiterpene is one of main chemical constituents of Miliusa velutina.

In this paper, seven compounds were isolated from Miliusa velutina for the first time. Among them, there are two new sesquiterpenes, mivelutina A acid (1) and mivelutina B acid (2), along with three known sesquiterpenes (3-5) and two known phenylpropanoids $(6,7)$. Their structures were identified as mivelutina B methyl ester (3), canangalia G (4), canangalia H (5), vanillyl glycol (6), and epoxyconiferyl alcohol (7) (Figure 1). Compound $\mathbf{3}$ has been synthesized (Tamelen 1968; Tamelen et al. 1982), but it had not been named and no NMR spectral data were provided. All seven compounds were screened for their in vitro cytotoxic activities against HepG2 cell line using the SRB assay.

Recently, it has been demonstrated that absolute configuration can be determined based on ${ }^{13} \mathrm{C}$ calculated nuclear shieldings by Density Functional Theory (Kutateladze and Kuznetsov 2017). Furthermore, such DFT calculations may give other structural information, which can be essential with compounds containing in principle flexible six-membered rings. 


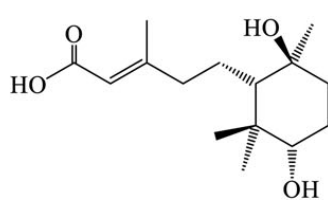

Mivelutina A acid (1)

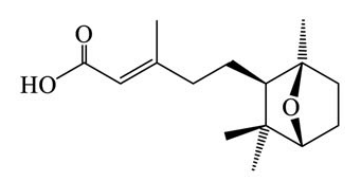

Mivelutina B acid (2)

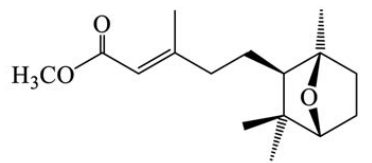

Mivelutina B methyl ester (3)<smiles>COC(=O)/C=C(\C)CCC1C(C)(C)CCC(O)C1(C)O</smiles>

Canangalia G (4)<smiles>COC(=O)/C=C(\C)CC[C@@H]1C(C)(C)CC[C@H](O)C1(C)C</smiles>

Canangalia H (5)<smiles>COc1cc(CC(O)CO)ccc1O</smiles>

Vanillyl glycol (6)

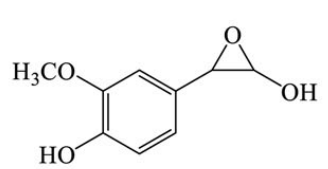

Epoxyconiferyl alcohol (7)

Figure 1. Structures of isolated compounds.

\section{Results and discussion}

\subsection{Identification}

Compound 1 was isolated as a white amorphous powder. Its HR-ESI-MS showed the sodium adduct ion at $m / z 293.1716[\mathrm{M}+\mathrm{Na}]^{+}$(calcd. for $\mathrm{C}_{15} \mathrm{H}_{26} \mathrm{O}_{4} \mathrm{Na}, 293.1729$ ). The ${ }^{1} \mathrm{H} \mathrm{NMR}$ spectrum showed the presence of an olefinic proton at $\delta_{\mathrm{H}} 5.56(1 \mathrm{H}, b r s)$ and one oxymethine proton at $\delta_{\mathrm{H}} 3.06(1 \mathrm{H}, d d, J=10.5,4.0 \mathrm{~Hz})$. In addition, four methyl signals at $\delta_{\mathrm{H}} 2.05(3 \mathrm{H}, s)$, $0.66(3 \mathrm{H}, s), 0.90(3 \mathrm{H}, s)$, and $1.01(3 \mathrm{H}, s)$. The ${ }^{13} \mathrm{C}$ NMR spectrum showed the presence of 15 carbon resonances, consisting of one carboxyl carbon at $\delta_{\mathrm{C}} 168.8(\mathrm{C}-1)$, two olefinic carbons at $\delta_{\mathrm{C}} 118.0(\mathrm{C}-2)$ and $156.4(\mathrm{C}-3)$, two oxymethine carbons at $\delta_{\mathrm{C}} 71.8\left(\mathrm{C}-2^{\prime}\right)$ and $76.6\left(\mathrm{C}-5^{\prime}\right)$, four methyl carbons at $\delta_{\mathrm{C}} 18.4(\mathrm{C}-6), 15.2\left(\mathrm{C}-7^{\prime}\right), 28.3\left(\mathrm{C}-8^{\prime}\right)$, and $23.0\left(\mathrm{C}-9^{\prime}\right)$.

The HMBC correlations from H-1' to C-4, C-5, C-2', C-5', C-7', and C-9' established the cyclization between $\mathrm{C}-1^{\prime}$ and $\mathrm{C}-6^{\prime}$. The signal at $\delta_{\mathrm{H}} 3.06\left(1 \mathrm{H}, d d, J=10.5,4.0 \mathrm{~Hz}, \mathrm{H} 5^{\prime}\right)$ with coupling constants $10.5 \mathrm{~Hz}\left(J_{a a}\right)$ and $4.0 \mathrm{~Hz}\left(J_{a e}\right)$ suggested that $\mathrm{H}^{\prime}$ ' was axial. The HMBC correlation between $\mathrm{H} 2 / \mathrm{C} 1,4,6, \mathrm{H} 6 / \mathrm{C} 1,2,3,4, \mathrm{H} 4 / \mathrm{C} 2,3,5,6$, and $\mathrm{H} 5 / \mathrm{C}^{\prime}, 2^{\prime}$ ' showed that the $\alpha, \beta$ unsaturated acid moiety attached to the ring. The double bond on this chain was assigned the configuration $E$, which is evidenced by the position of the $\mathrm{H} 6$ at $\delta_{\mathrm{H}} 2.05$ (Ogura et al. 1970). Moreover, the relative configuration of $\mathbf{1}$ was established by analyzing the NOESY spectrum 
(Figure S3). The NOESY experiment showed correlations between $\mathrm{H} 1^{\prime} / \mathrm{H}^{\prime} / \mathrm{CH}_{3}-8^{\prime}$ which indicated that these protons are the same side. Based on all the aforementioned analysis, compound 1 was identified as (2E)-5-(2',5'-dihydroxy-2',6',6'-trimethylcyclohexyl)-3-methyl2-pentenoic acid which was named mivelutina A acid. The absolute configuration of compound 1 was determined by the DFT calculations.

Compound 2 was isolated as a white powder. The HR-ESI-MS $275.1635[\mathrm{M}+\mathrm{Na}]^{+}$ (calcd. for $\mathrm{C}_{15} \mathrm{H}_{24} \mathrm{O}_{3} \mathrm{Na}$, 275.1623) suggested the molecular formula $\mathrm{C}_{15} \mathrm{H}_{24} \mathrm{O}_{3}$ and the four degrees of unsaturation of compound 2. The NMR data of $\mathbf{2}$ were similar to $\mathbf{1}$, except the main differences of chemical shifts at $\mathrm{C} 2^{\prime}$ (86.8) and $\mathrm{C}^{\prime}$ (86.3) of 2 and at $\mathrm{C} 2^{\prime}$ (71.8), $\mathrm{C} 5^{\prime}$ (76.6) of 1, demonstrating that compound $\mathbf{2}$ was derivative of compound $\mathbf{1}$. These differences along with HR-ESI-MS, suggested the ether cyclization of two hydroxyl groups at $\mathrm{C}^{\prime}$ and $\mathrm{C}^{\prime}$ of $\mathbf{1}$ to form 2. Besides, the correlation $\mathrm{HMBC}$ between $\mathrm{H}^{\prime}$ and $\mathrm{C} 2^{\prime}$ confirmed the ether bridge structure of 2 (Figure S4). From all data, compound 2 was determined as $(2 E)-5-\left(2^{\prime}, 5^{\prime}\right.$-epoxy2',6',6'-trimethylcyclohexyl)-3-methyl-2-pentenoic acid which was named mivelutina B acid. For absolute configuration see later.

Compound 3 was isolated as a colourless oil. The HR-ESI-MS 267.1977 $[\mathrm{M}+\mathrm{H}]^{+}$ (calcd. for $\mathrm{C}_{16} \mathrm{H}_{27} \mathrm{O}_{3}, 267.1960$ ) suggested the molecular formula $\mathrm{C}_{16} \mathrm{H}_{26} \mathrm{O}_{3}$ and the four degrees of unsaturation of compound 3. The NMR data of $\mathbf{3}$ exhibited similar signals of 2 . However, one more methoxy signal at $\delta_{\mathrm{H}} 3.69(3 \mathrm{H}, s)$ in the ${ }^{1} \mathrm{H}$ NMR spectrum and at $\delta_{\mathrm{C}} 51.0$ ppm was seen in the ${ }^{13} \mathrm{C}$ NMR spectrum. Consequently, compound $\mathbf{3}$ was the methyl ester of compound 2. The NOESY experiment showed correlations between $\mathrm{H} 2 / \mathrm{H} 4$ showed the $\mathrm{C} 2=\mathrm{C} 3$ double bond was assigned the configuration $E$ (Figure S5). The compound was named mivelutina B methyl ester. For absolute configuration see later. 
The known compounds were identified as canangalia $G$ (4), canangalia $H$ (5) (Phatchana et al. 2016), vanillyl glycol (6) (Yadav et al. 2014), epoxyconiferyl alcohol (7) (Kostova et al. 1995), by comparison of their NMR data with those reported in the literature.

\subsection{DFT calculations and determination of absolute configuration}

Structures have been calculated using the DFT functional, B3LYP and the Pople basis set $\mathrm{G}(\mathrm{d})$. In case of $\mathbf{1}$ common for all eight isomers is that the six-membered ring takes up a boat like structure (Figure S6).

To test the use of DFT calculations to determine absolute configurations, this is first done on compound 2. As seen from the plots of the best and good correlation is found for structure H-1'ax (Figure S7). This leads to the structure of compound 2 (Figure S8). This structure is also confirmed by an almost non-existing NOESY cross peak between H-1' and $\mathrm{CH}_{3}-9^{\prime}$. The structure of compound 2 is $\left(2 E, 1^{\prime} R, 2^{\prime} S, 5^{\prime} R\right)-5-\left(2^{\prime}, 5^{\prime}-\right.$ epoxy-2', $6^{\prime}, 6^{\prime}-$ trimethylcyclohexyl)-3-methyl-2-pentenoic acid.

This confirms that the functionality, B3LYP and the basis set G(d) can be used. In case of compound $\mathbf{1}$ all eight isomers are calculated. Four of these I, III, V and VII (Figure S27) do not fulfil the criteria of $\mathrm{H}^{-5}$ ' being axial. Of the remaining, VIII has by far the highest correlation coefficient. The interesting feature is that the large substituent at $\mathrm{C}-1$ 'is axial. However, this avoids heavy steric interaction with the methyl groups $8^{\prime}$ and $9^{\prime}$. It is also obvious that the NOESY information is fulfilled by this structure. The structure for $\mathbf{1}$ is $\left(2 E, 1^{\prime} S, 2^{\prime} S, 5^{\prime} S\right)-5-\left(2^{\prime}, 5^{\prime}\right.$-dihydroxy-2',6',6'-trimethylcyclohexyl)-3-methyl-2-pentenoic acid. This structure is quite different from the structure proposed by Phatchana et al. 2016 for the corresponding ester. 


\subsection{Biological tests}

The isolated compounds were tested for the cytotoxicity against the cancer cell line Hepatoma G2 (HepG2). Camptothecin ( $\left.\mathrm{IC}_{50} 0.05 \mu \mathrm{g} / \mathrm{mL} ; 0.14 \mu \mathrm{M}\right)$ was used as a positive control, with a cytotoxic value of $55.83 \%$. Interesting points related to structures and activities can be seen. The epoxycyclization of compound 7 (epoxyconiferyl alcohol) caused the cytotoxicity to be significantly increased compared to compound 6 (vanillyl glycol) with cytotoxic values of $54.38 \%$ and $-2.87 \%$, respectively. Besides, the methyl ester group of compound 3 (mivelutina B methyl ester) had a marked effect on the cytotoxicity compared to that of compound 2 (mivelutina B acid) being the corresponding acid with cytotoxic values of $35.18 \%$ and $-4.99 \%$, respectively.

Epoxyconiferyl alcohol (7) showed the highest cytotoxic value of $54.38 \%$ and an $\mathrm{IC}_{50}$ value of $95.94 \mu \mathrm{g} / \mathrm{mL}(527 \mu \mathrm{M})$. The remaining compounds (1-6) with cytotoxic percent values lower than $50 \%$, did not show cytotoxicity (Table S2).

\section{Experimental}

\subsection{General experimental procedures}

Optical rotations were measured on an A. Krüss Optronic polarimeter P3000 (Krüss Optronic GmbH, Hamburg, Germany). The ${ }^{1} \mathrm{H}$ NMR (500 MHz) and ${ }^{13} \mathrm{C}$ NMR $(125 \mathrm{MHz})$ spectra were recorded by a Bruker AM500 FT-NMR spectrometer. HR-ESI-MS data were acquired on Bruker micrOTOF QII (Bruker Singapore Pte., Ltd.) mass spectrometer. Column chromatography (CC) was performed on silica gel (Merck) type 0.063-0.200 mm ASTM, silica gel (Himedia) type 37-63 $\mu m$ GRM7484-500G, and LiChroprep® RP-18, 40-63 ${ }^{\circledR}$ (Merck KGaA, Darmstadt, Germany). Analytical and preparative TLC was carried out on pre-coated Kieselgel 60F-254 or RP-18 plates (Merck KGaA, Darmstadt, Germany). Optical density values were determined with a 96-well microtiter plate reader (Synergy HT, Biotek Instruments). Other chemicals were of the highest grade available. 


\subsection{Plant material}

The stems of Miliusa velutina were collected in September 2016 in An Giang province, Vietnam and were authenticated by Master Viet Hoang, Department of Ecology - Evolutionary Biology, Faculty of Biology - Biotechnology, VNUHCM-University of Science, Ho Chi Minh City. A voucher specimen (MVE 2016) has been deposited at the Department of Organic Chemistry, Faculty of Chemistry, VNUHCM-University of Science.

\subsection{Extraction and isolation}

The stems of Miliusa velutina were ground into powder. The plant material $(9.5 \mathrm{~kg})$ was then extracted under reflux successively with $n$-hexane, ethyl acetate, and methanol to obtain three corresponding extracts: n-hexane (84.9 g), ethyl acetate (62.2 g), and methanol $(500.0 \mathrm{~g})$. The ethyl acetate extract was chromatographed on silica gel column and eluted using solvents with $n$-hexane:ethyl acetate (7:3-0:10), ethyl acetate:methanol (10:0-5:5), and methanol (100\%), to afford 11 fractions (EA1-EA11). Fraction EA7 (3.3 g) was subjected to silica gel column chromatography and eluted with chloroform:methanol several times, to yield compound 1 (6.9 mg). Fraction EA2 ( $0.6 \mathrm{~g})$ was separated by column chromatography on silica gel and eluted with $n$-hexane:ethyl acetate, to afford two sub-fractions (EA2.1 and EA2.2). Sub-fraction EA2.1 chromatographed over silica gel column with $n$-hexane:ethyl acetate $(8: 2-$ 0:10), to yield compound 3 (4.2 mg). Sub-fraction EA2.1 purified by preparative TLC with $n$ hexane:ethyl acetate:methanol (16:4:0.5), to yield compound 2 (3.7 mg). Fraction EA5 (5.9 g) was subjected to silica gel column and eluted with $n$-hexane:ethyl acetate (7:3-0:10), and methanol, to yield compounds $4(5.9 \mathrm{mg}), \mathbf{5}(32.3 \mathrm{mg})$, and $7(4.0 \mathrm{mg})$. Fraction EA8 $(1.1 \mathrm{~g})$ was separated over a Sephadex LH-20 column with chloroform:methanol (5:5), to afford four sub-fractions (EA8.1-4). Sub-fraction EA8.4 was purified by preparative TLC with $n$ hexane:chloroform:methanol (5:4.5:0.5), to yield compound 6 (30.9 mg).

\subsubsection{Mivelutina A acid (1)}


White powder; $[\alpha]_{D}^{25}+18.6(c 0.1, \mathrm{MeOH}),{ }^{1} \mathrm{H}$ NMR $\left(500 \mathrm{MHz}, \mathrm{DMSO}-d_{6}\right)$ and ${ }^{13} \mathrm{C} \mathrm{NMR}$ (125 MHz, DMSO-d6), see supplementary Table S1; HR-ESI-MS m/z 293.1716 [M+Na] ${ }^{+}$ (calcd. for $\mathrm{C}_{15} \mathrm{H}_{26} \mathrm{O}_{4} \mathrm{Na}, 293.1729$ ).

\subsubsection{Mivelutina B acid (2)}

White powder; $[\alpha]_{D}^{25}+22.5(c 0.1, \mathrm{MeOH}),{ }^{1} \mathrm{H}$ NMR $\left(500 \mathrm{MHz}, \mathrm{CDCl}_{3}\right)$ and ${ }^{13} \mathrm{C} \mathrm{NMR}(125$ $\mathrm{MHz}, \mathrm{CDCl}_{3}$ ), see supplementary Table S1; HR-ESI-MS $275.1635[\mathrm{M}+\mathrm{Na}]^{+}$(calcd. for $\left.\mathrm{C}_{15} \mathrm{H}_{24} \mathrm{O}_{3} \mathrm{Na}, 275.1623\right)$.

\subsubsection{Mivelutina B methyl ester (3)}

Colourless oil; $[\alpha]_{D}^{25}+16.5(c$ 0.1, $\mathrm{MeOH}),{ }^{1} \mathrm{H}$ NMR (500 MHz, $\left.\mathrm{CDCl}_{3}\right)$ and ${ }^{13} \mathrm{C} \mathrm{NMR}(125$ $\mathrm{MHz}, \mathrm{CDCl}_{3}$ ), see supplementary Table S1; HR-ESI-MS $267.1977[\mathrm{M}+\mathrm{H}]^{+}$(calcd. for $\left.\mathrm{C}_{16} \mathrm{H}_{27} \mathrm{O}_{3}, 267.1960\right)$.

\subsection{Cell Lines and Cell Culture}

HepG2 cells were purchased from the American Type Culture Collection (Manassas, Rockville). Cells were cultured at $37^{\circ} \mathrm{C}$ and $5 \% \mathrm{CO}_{2}$ in Eagle's Minimal Essential Medium (EMEM) supplemented with $10 \%$ (v/v) FBS (Sigma-Aldrich), 2 mM L-glutamine (SigmaAldrich), $20 \mathrm{mM}$ HEPES (Sigma-Aldrich), $0.025 \mu \mathrm{g} \mathrm{mL} \mathrm{m}^{-1}$ amphotericin B (Sigma-Aldrich), $100 \mathrm{IU} \mathrm{mL} \mathrm{m}^{-1}$ penicillin $\mathrm{G}$ (Sigma-Aldrich), and $100 \mu \mathrm{g} \mathrm{mL}^{-1}$ streptomycin (Sigma-Aldrich).

\subsection{Cytotoxic activity evaluated by SRB assay}

The assay was performed as previously described with some modifications (Vistica et al. 1990). Cells were seeded at a density of 10,000 cells/well (HepG2) in 96-well plates. Cells were cultured for $24 \mathrm{~h}$ before being incubated with isolated compounds at different concentrations for $48 \mathrm{~h}$. Treated cells were fixed with cold $50 \%(\mathrm{w} / \mathrm{v})$ trichloroacetic acid (Merck KGaA) for 1-3 h, washed and stained with $0.2 \%$ (w/v) SRB (Sigma-Aldrich) for 20 
min. After five washes with $1 \%$ acetic acid (Merck KGaA), the protein-bound dye was solubilized in $10 \mathrm{mM}$ Tris base solution (Promega). Optical density values were determined at the wavelengths of $492 \mathrm{~nm}$ and $620 \mathrm{~nm}$. The percentage of growth inhibition (Inh \%) was calculated according to the formula: Inh $\%=(1-[\mathrm{ODt} / \mathrm{ODc}] \times 100) \%$, in which ODt and ODc are the optical density value of the test sample and the control sample, respectively. Data were represented as means \pm standard error $(n \geq 3)$. The $\mathrm{IC}_{50}$ value was determined by using Prism software with multivariate nonlinear regression and $\mathrm{R}^{2}>0.9$. Camptothecin (Merck $\mathrm{KGaA}$ ) was used as a positive control.

\subsection{Calculations}

Molecular geometries were optimised using Gaussian 09 suite of programs (Frisch et al. 2009). Density functional theory, combined with the widely used and efficient B3LYP hybrid functional exchange (Becke 1988) and correlation term (Lee, Yang, Parr 1988) and 6$31 \mathrm{G}(\mathrm{d})$ basis set were used for full structure optimization. The nuclear shielding calculations were performed using the gauge including atomic orbitals formalism (Wolinski et al 1990).

\section{Conclusions}

From the ethyl acetate extract of the stems of Miliusa velutina, seven compounds (17), including five sesquiterpenes (1-5) and two phenylpropanoids $(\mathbf{6}, 7)$ were isolated for the first time. Among them, there are two new compounds such as mivelutina A acid (1), mivelutina B acid (2) and one known compound such as mivelutina B methyl ester (3), which had been not previously provided the NMR data. Epoxyconiferyl alcohol (7) showed the highest potential for the cytotoxicity of cancer cell lines HepG2.

\section{Supplementary material}

NMR and MS spectra for the compounds (1-3). Cytotoxicity test in vitro in cancer cell lines HepG2 of the compounds (1-7). Plots of ${ }^{13} \mathrm{C}$ nuclear shieldings vs. ${ }^{13} \mathrm{C}$ chemical shifts.

\section{Acknowledgment}


This research is funded by Vietnam National University HoChiMinh City (VNU-HCM) under grant number C2017-18-10.

\section{Disclosure statement}

No potential conflict of interest was reported by the authors.

\section{References}

Becke AD. 1988. Density-functional exchange-energy approximation with correct asymptoticbehavior. Phys. Rev. A., 38: 3098-3100.

Faria A, Pestana D, Teixeira D, de Freitas V, Mateus N, Calhau C. Blueberry anthocyanins and pyruvic acid adducts: Anti-cancer properties in breast cancer cell lines. Phytother. Res. 24:1862-9.

Gaussian 09, Revision D.01, M. J. Frisch, G. W. Trucks, H. B. Schlegel, G. E. Scuseria, M. A. Robb, J. R. Cheeseman, G. Scalmani, V. Barone, B. Mennucci, G. A. Petersson, H. Nakatsuji, M. Caricato, X. Li, H. P. Hratchian, A. F. Izmaylov, J. Bloino, G. Zheng, J. L. Sonnenberg, M. Hada, M. Ehara, K. Toyota, R. Fukuda, J. Hasegawa, M. Ishida, T. Nakajima, Y. Honda, O. Kitao, H. Nakai, T. Vreven, J. A. Montgomery, Jr., J. E. Peralta, F. Ogliaro, M. Bearpark, J. J. Heyd, E. Brothers, K. N. Kudin, V. N. Staroverov, R. Kobayashi, J. Normand, K. Raghavachari, A. Rendell, J. C. Burant, S. S. Iyengar, J. Tomasi, M. Cossi, N. Rega, J. M. Millam, M. Klene, J. E. Knox, J. B. Cross, V. Bakken, C. Adamo, J. Jaramillo, R. Gomperts, R. E. Stratmann, O. Yazyev, A. J. Austin, R. Cammi, C. Pomelli, J. W. Ochterski, R. L. Martin, K. Morokuma, V. G. Zakrzewski, G. A. Voth, P. Salvador, J. J. Dannenberg, S. Dapprich, A. D. Daniels, Ö. Farkas, J. B. Foresman, J. V. Ortiz, J. Cioslowski, and D. J. Fox, Gaussian, Inc., Wallingford CT, 2009.

Hasan CM, Jumana S, Rashid MA. 2000. (+)-Isocorydine $\alpha$ - $N$-Oxide: A new aporphine alkaloid from Miliusa velutina. Nat. Prod. Lett. 14: 393-397.

Jumana S, Hasan C M, Rashid MA. 2000. Alkaloids from the stem bark of Miliusa velutina. Biochem. Syst. Ecol. 28: 483-485. 
Jumana S, Hasan CM, Rashid MA. 2000. Antibacterial activity and cytotoxicity of Miliusa velutina. Fitoterapia. 71: 559-561.

Kostova I, Dinchev D, Mikhova B, Iossifova T. 1995. Epoxyconiferyl alcohol from Fraxinus oxycarpa bark. Phytochemistry. 38: 801-802.

Kutateladze A.G. and Kuznetsov D.M.2017. Triquinanes and Related Sesquiterpenes Revisited Computationally: Structure Corrections of Hirsutanols B and D, Hirsutenol E, Cucumin B, Antrodins C-E, Chondroterpenes A and H, Chondrosterins C and E, Dichrocephone A, and Pethybrene. J. Org. Chem. 82, 10795-10802.

Lee C, Yang W, Parr RG.1988. Development of the Colle-Salvetti correlation-energy formula in a functional of the electron-density. Phys. Rev. B 37:785-789.

Nguyen DMT, Vo TN, Ton-That Q, Nguyen KPP. 2015. Alkaloids from Miliusa velutina. Vietnam J. Chem. 53: 85-88.

Phatchana R, Thongsri Y, Yenjai C. 2016. Canangalias C-H, juvenile hormone III analogues from the roots of Cananga latifolia. Fitoterapia. 114: 45-50.

Tamelen EEV. 1968. Bioorganic Chemistry: Sterols and acyclic terpene terminal epoxides. Acc. Chem. Res. 1: 111-120.

Tamelen EEV, Storni A, Hessler EJ, Schwartz MA. 1982. Cyclization studies with ( \pm )-10,11oxidofarnesyl acetate, methyl farnesate, and methyl $( \pm)$-10,11-oxidofarnesate. Bioorg. Chem. 11: 133-170.

Vistica D, McMahon J, Warren JT, Skehan P, Storeng R, Kenney S, Monks A, Scudiero D, Bokesch H, Boyd MR. 1990. New colorimetric cytotoxicity assay for anticancer-drug screening. J. Natl. Cancer Inst. 82:1107-1112.

Vo VC. 1991. An Giang medicinal plants. An Giang Science - Technology Committee, 154155. 
Wolinski K, Hinton JF and Pulay P.1990 Efficient implementation of the gauge-independent atom orbital method for NMR chemical-shift calculations. J. Am. Chem. Soc. 112:8251-8260.

Wongsa N, Kanokmedhakul K, Boonmak J, Youngme S, Kanokmedhakula S. 2017. Bicyclic lactones and racemic mixtures of dimeric styrylpyrones from the leaves of Miliusa velutina. RSC Advances. 7: 25285-25297.

Wongsa N, Kanokmedhakul S, Kanokmedhakul K. 2011. Cananginones A - I, linear acetogenins from the stem bark of Miliusa velutina. Phytochemistry. 72: 1859-1864.

Yadav Y, Owens EA, Sharma V, Aneja R, Henary M. 2014. Synthesis and evaluation of antiproliferative activity of a novel series of hydroxychavicol analogs. Eur.J.Med. Chem. 75: 1-10. 